\author{
Zbigniew Marek* \\ ORCID: 0000-0002-4580-1819 \\ Janusz Mótka** \\ ORCID: 0000-0002-1488-6100 \\ Anna Walulik*** \\ ORCID: 0000-0002-5607-6974 \\ Kraków, Poland
}

\title{
Integral Upbringing Inspired by Gospel
}

\section{Wychowanie integralne inspirowane Ewangelią}

Summary: The concept of integral education comprises multifaceted pedagogical measures supporting the person in achieving the highest possible level of maturity. The authors of the article seek the explanations for the meaning of the Gospel -

* Prof. PhD hab. Zbigniew Marek SJ, Department of Andragogy and Pedagogical Axiology in the Institute of Educational Sciences, Faculty of Pedagogy in Jesuit University Ignatianum in Cracow. Correspondence: Akademia Ignatianum w Krakowie, Instytut Nauk o Wychowaniu, ul. Kopernika 26, 31-501 Kraków, Poland; e-mail: zmarek@ignatianum.edu.pl.

** Phd Janusz Mółka, the Institute of Educational Sciences, the Faculty of Pedagogy in Jesuit University Ignatianum in Cracow. Correspondence: Akademia Ignatianum w Krakowie, Instytut Nauk o Wychowaniu, ul. Kopernika 26, 31-501 Kraków, Poland; e-mail: janusz. molka@ignatianum.edu.pl.

*** Phd hab. Anna Walulik, prof. of Jesuit University Ignatianum in Cracow, Head of Department of Andragogy and Pedagogical Axiology in the Institute of Educational Sciences in the Faculty of Pedagogy in Jesuit University Ignatianum in Cracow. Correspondence: Akademia Ignatianum w Krakowie, Instytut Nauk o Wychowaniu, ul. Kopernika 26, 31-501 Kraków, Poland; e-mail: walulika@gmail.com. 
the source of Christianity - for the processes of education. Their explanations focus on the three aspects of the Gospel-inspired, broadened view of life. It expresses itself in a new perspective on life, the discovery of its goal and the new quality of life proposed in the Gospel. This analysis of the biblical pericope (Matt 19: 16-22) hence enables us to argue that the integral education belongs to the tradition of the transcendent pedagogy. It supports the person in discovering his/her dignity and fosters her/his development, corporal as well as spiritual. The discovery of the person's capabilities opens him/her up to the reality of the non-material world and to the Transcendence - the personal God. Thanks to this property, the integral upbringing reveals a new quality of life. It goes from respecting the dignity of both the student and the educator, which makes it possible to establish and develop both interpersonal relationships and a relationship with God. This approach, in turn, makes us aware that the Christian religion and its foundation, Gospel, provide the new educational tools for the pedagogues.

Keywords: integral education; religion; Gospel; new quality of life.

Streszczenie: Wychowaniem integralnym nazwane zostały wieloaspektowe zabiegi wychowawcze, których celem jest wspomaganie rozwoju osoby po to, by była ona w stanie osiągnąc możliwie wysoki stopień dojrzałości. Autorzy artykułu zmierzają do wyjaśnienia znaczenia - stanowiącej źródło chrześcijaństwa - Ewangelii dla procesów wychowania. Swe objaśnienia opierają na trzech aspektach poszerzających sposób patrzenia na życie dzięki przyjęciu Ewangelii. Wyraża się on w nowym postrzeganiu życia, odkrywaniu jego celu oraz nowej jakość zaproponowanej w Ewangelii. Analiza perykopy biblijnej (Mt 19, 16-22) pozwoliła wskazać, że wychowanie integralne wpisuje się w nurt pedagogiki transcendentnej. Pełni ono funkcję wspomagającą osobę w odkrywaniu własnej godności i przyczynia się do jej rozwoju cielesnego i duchowego. Odkrycie przez człowieka swych możliwości otwiera go na rzeczywistość świata niematerialnego i na samą Transcendencję osobowego Boga. Dzięki tej właściwości wychowanie integralne odsłania przed człowiekiem nową jakość jego życia. Wynika ona najpierw z podmiotowego postrzegania osoby zarówno wychowanka, jak i wychowawcy, co umożliwia nie tylko nawiązywanie i rozwijanie relacji międzyludzkich, ale też relacji z Bogiem. To z kolei uświadamia, że religia chrześcijańska i stanowiąca jej podstawy Ewangelia dostarczają wychowaniu nowych narzędzi umożliwiających wspomaganie procesów wychowania.

Słowa kluczowe: wychowanie integralne; religia; Ewangelia; nowa jakość życia. 
Integral upbringing can be understood as the multifaceted acts of doing, which are aimed at giving the processes of upbringing the rank of acts supporting ${ }^{1}$ the development of a person in order to achieve a high level of maturity ${ }^{2}$. They are based on different sources; hence, from the perspective of the pedagogy of religion, Gospel can be taken as one of them. In this context, the query seems significant about the scope of Gospel can lead to inspiration for upbringing acts of doing. To answer to this question we are going to look for through the categorial analysis ${ }^{3}$ of the Bible text (Mt 19: 16-22). We seek this interpretation in the context of the pedagogy of accompaniment. Here we have the Bible narration we treat as an experience, while indicating the category (actors, place, time and expectations) means the fundamental of reflection, while its interpretation refers to the acts of doing and assessment ${ }^{4}$.

The aim of this article is to show the potential of Gospel for the integral upbringing, which refers not only to the natural basis of human development but also includes his/her references to transcendence ${ }^{5}$. This relation comes from the belief that as there is no pedagogy without transcendence, so the integral upbringing is not possible without references to transcendence ${ }^{6}$. The integral upbringing assumes to have an even impact, through which it shapes the man's somatic, psychic, and spirituals sphere in a clearly defined perspective and far-reaching goal which Christianity takes for granted as the references to Transcendence - Personal God. In the reflection conveyed by us, we restrict ourselves to the explanations provides by the Catholic pedagogy coming from the pedagogy of religion. These terms are understood by us a theory of upbringing that has been worked out in the mainstream of hu-

${ }^{1}$ Katarzyna Olbrycht, „Wychowanie do wartości - w centrum aksjologicznych dylematów współczesnej edukacji”, Paedagogia Christiana 1/29 (2012): 89-92.

2 Por. Jerzy Bagrowicz, „Godność osoby fundamentem wychowania”, in: Wychowanie personalistyczne, ed. Franciszek Adamski (Kraków: WAM, 2005), 207-208.

${ }_{3}$ Zbigniew Marek, Anna Walulik, Pedagogika świadectwa. Perspektywa antropologiczno-kerygmatyczna (Kraków: AIK, w druku).

${ }^{4}$ Zbigniew Marek, Pedagogika towarzyszenia. Perspektywa tradycji ignacjańskiej (Kraków: AIK, 2017).

5 Jarosław Michalski, „Kształcenie ogólne czy specjalistyczne? A może jedno i drugie ...”, Paedagogia Christiana 1/29 (2012): 179-180.

${ }^{6}$ Bogusław Śliwerski, „Pedagogika bez transcendencji”, in: Pedagogika ignacjańska wobec wyzwań współczesnego humanizmu, ed. Wit Pasierbek (Kraków: WSF-P Ignatianum, WAM, 2008), 79-108. 
manities and the Catholic theology enabling the interpretation of the reality of human life in the light of the Catholic Church contents and requirements?

\section{Gospel shows the fundamentals of successful life}

Presented above the way of understanding the religion contribution to the processes of integral development draws its source from Gospel. A dialogue between Jesus and a young man (Mt 19: 16-22) can serve as a characteristic example.

16 Just then a man came up to Jesus and asked, "Teacher, what good thing must I do to get eternal life?" 17 "Why do you ask me about what is good?" Jesus replied. "There is only One who is good. If you want to enter life, keep the commandments". 18 "Which ones?" he inquired. Jesus replied, "You shall not murder, you shall not commit adultery, you shall not steal, you shall not give false testimony, 19 honour your father and mother, and love your neighbour as yourself!" 20 "All these I have observed", the young man said. "What do I still lack?" 21 Jesus answered, "If you want to be perfect, go, sell your possessions and give to the poor, and you will have treasure in heaven. Then, come, follow me!".

While reading this text, one might, first of all, notice that the young man asks Jesus "What good thing must I do to get eternal life?" (v. 16). This phrase shows that Jesus is someone extraordinary. He is an authority able to give answers to crucial, existential question concerning eternal life. This dialogue can be compared to two visions connected with the realisation of eternal life. One vision presents the young man's attitude who thinks that he can guarantee himself the goal of life which he asks - the eternal life. In such a way, he expresses the egocentric desire for eternal life and feeling that can achieve it with own good.

However, Jesus asks him "Why do you ask me about what is good?" (v. 17) and sends to the Only One who is good, to God who can make the young man's desire true. Jesus makes allusion to the spoken words 'Szema' - "Listen Israeli! LORD is our God, the only one LORD. You shall love LORD, your God" (Deuteronomy 6: 4-5). In Izraelitas' consciousness, it has

7 Zbigniew Marek, Anna Walulik, „Pedagogika katolicka w perspektywie pedagogiki transcendentnej”, Horyzonty Wychowania 38 (2017): 125-141. 
built the belief that any activity made by the faithful man has to be motivated by love to God. In this light, Jesus says to him about the need of observing the commandments that appear to be fundamental for relationship between God and people ${ }^{8}$.

The dialogue conducted by the young man with Jesus pays attention to the 'otherness' of Jesus. He proposes that man has a new quality of life which is not going to provide him the eternal life, but will, first and foremost, provide him with perfection. The only one condition is to "go, sell your possessions and give to the poor, and you will have treasure in heaven. Then come, follow Me!" (v. 21). In this phrase we have to do with the indication that shifts the accent from what man possesses - material things - to his own person, what Jesus regards as necessary. Thus, reaching the perfectibility is possible only through getting relationship with Jesus and following Him, going the way shown by Him. We can say that Jesus outlines new horizons of life in front of man; namely, the perfection that his reason can't encompasses.

Hans Waldenfels explains that following Jesus Christ should be considered in three dimensions: vocation, conversion and sending ${ }^{9}$. In discussing the matter of vocation, the author pays attention to Jesus' meeting with a concrete man. In the pericope analysed, the man is the young man. In this meeting, one can observe graduating the demands posed by Jesus. "Replied Him: [...] «If you want to enter life, keep the commandments»" (v. 17), and after the positive man's answer: "All these I have kept" (v. 20). Jesus draws a next challenge: "If you want to be perfect, go, sell your possessions and give to the poor, and you will have treasure in heaven. Then come, follow me!" (v. 21). The consequence of acceptance of Jesus' calling - "being His disciple" - is the man's conversion.

The meaning of this passage concerns the change of way of thinking and acting, the attitude of radical tearing off the bonds with everything - the bonds that enable the man following Jesus Christ. Referring to the third dimension that explicates the sense of following Jesus, Hans Waldenfels connects with the contribution between Jesus' mission and the world. Its sense means, first of all, to fulfil God Father's will so that the man could regain the

8 Adrian Leske, „Ewangelia według św. Mateusza”, in: Międzynarodowy komentarz do Pisma Świętego. Komentarz katolicki i ekumeniczny na XXI wiek, ed. Waldemar Chrostowski (Warszawa: Verbinum, 2000), 1186; por. Jan Charytański, Rzeczywistość miłości w Katechizmie Kościoła katolickiego (Kraków: WAM, 1998), 13 i nn.

${ }^{9}$ Hans Waldenfels, O Bogu, Jezusie Chrystusie i Kościele dzisiaj. Teologia fundamentalna w kontekście czasów obecnych (Katowice: Księgarnia św. Jacka, 1993), 279-281. 
prime friendship with God torn off by sin. At last, the reality of the mission comprises the man's contribution into the mission of Jesus Christ; restoring the harmony between Creator and the creature - God and man. Jesus realises this mission by preaching the approach of kingdom of God.

Here, the characteristic fact is that this preaching takes place not by forcing people to accept His idea, but on the way of love and servitude. Discussing the matters of the man's contribution in Jesus mission, Waldenfels first considers the development of the readiness for acts of love and servitude of which Jesus spoke about and by proving it unquestionably in his passion and while being crucified to death. Hence, following Jesus cannot be identified only with imitating one's Master, as it could be identified only with behaviour. It is about something more; it is about the same spirit, the same feelings which are the qualities of Jesus Christ. These qualities enable man to imitate Him; Man nurturing self through these qualities and participating in Jesus' mission, what makes him His witness.

The lecture of Mathew's pericope enables stating that the young man's question about "eternal life"; in fact, it is every man's inquiry about lasting, happiness, love, etc. Life shows that answers for this question can be different. Without any discussion which one would be the most appropriate, we stop upon the answer given the young man by Jesus: "If you want to enter life, keep the commandments" (v. 17). Can this answer possess connections with the integral upbringing? To reply constructively to this question, it is worth reminding that God commandments - Decalogue summarises the principles of natural law, inscribed in the man's nature ${ }^{10}$. They are said to describe a moral order obligatory for the man. It is crucial to say that that man does not create this order, but only discovers it and reads.

In the Christian interpretation of natural law ${ }^{11}$, one should pay attention to the fact that it is nothing else but the light of cognition laid in man by God. Thanks to this law, man is able to recognise what he should do and what he should avoid ${ }^{12}$. Hence, this law is a perfect masterpiece of the Creator providing solid foundations on which man can raise a construction of moral principles for building the human being community. At last, this provides a necessary basis for the civil law, which is tied up with it either through

${ }^{10}$ Por. Eleonore Beck, „Dekalog”, in: Praktyczny słownik biblijny, ed. Anton Grabner-Haider (Warszawa: IW PAX, Wyd. Księży Pallotynów, 1994), 229.

${ }^{11}$ Giuseppe Mari, „Chrześcijaństwo a humanizm. Szanse i wyzwania w zsekularyzowanej kulturze", Paedagogia Christiana 1/39 (2017): 20-24.

${ }^{12}$ Katechizm Kościoła Katolickiego (Poznań: Pallottinum, 1994), nr 1958. 
reflection which produces the implications from its principles, or through the completion which has a positive and legal feature ${ }^{13}$.

Christianity treats the natural law as a foundation of revelation law transferred to man by God ${ }^{14}$, which is evoked by Jesus giving an evangelic man the answer to the question about the possibility of reaching the eternal life: "You shall not murder, you shall not commit adultery, you shall not steal, you shall not give false testimony, honour your father and mother, and love your neighbour as yourself!" (v. 18-19). Recommendation of love to another person has been shown here as summary of former commandments. This course of thinking makes us aware of the fact that love to another person comes from God's love ${ }^{15}$. Making an attempt to understand this statement correctly one should evoke earlier Jesus' explanations that every act of doing should be motivated by love to God: "There is only One who is good" (v. 17).

In practice, one can imply that God, through the commandments given to people, wants their good. This is the same good which is the object of search made by form-teachers for their pupils. We can say that through Decalogue God supports the integral upbringing. It is easy to notice that the commandment: "You shall not murder" certainly, supports the whole sphere connected with the human physical development. Similarly, the commandment: "You shall not commit adultery" can be referred to supporting the development of relationships between persons, while the commandment: "Honour your father and mother" makes these relationships concrete in referring to the relationships with those who are loved and have respect for life. Elsewhere, the commandment: "You shall not steal" demands respect for someone's value; the commandment: "You shall not give false testimony" teaches how to stand by the truth.

Furthermore, Jesus indicates that authentic achievement of the principles coming from the particular commandments which is the commandment of love to God and neighbour. One can say that love integrates all processes of upbringing because it is reflected in the responsibility for self and another person, desire of good for him/her in such a way that one seeks it for oneself.

Analysis of the Bible pericope can lead to general implications of the role of religious faith - faith in a personal God in the processes of integral upbringing. An appropriate understanding of this thought is gained from reli-

13 Ibidem, nr 1959.

${ }^{14}$ Por. Zbigniew Marek, Podstawy wychowania moralnego (Kraków: WSF-P „Ignatianum", WAM, 2005), 48-49.

${ }^{15}$ Leske, „Ewangelia”, 1186. 
gious knowledge and fosters a discovery of the value of reflection upon own life style ${ }^{16}$. This faith provides new motives that make a human being acting in more humanitarian way help man be purified from egoism. This humanisation defines the human perfection of oneself in its own existence.

What is more, if we look at this reality in the light of Jesus "new commandment of love", in which $\mathrm{He}$ insists on his disciples to make love that goes towards love of enemies, we can say that His Gospel brings human life a new quality. In the pedagogical practice, it is expressed through the attention paid to forming pupils with the human heart, ready for the noble acts of doing that are magnificent, deserving to man; undertaking the work upon self and carving for the harmony in social life. As a consequence, it indicates the importance of support given to pupils in the course of processes of achieving maturity and the importance of taking responsibility for self and others, so developing the interpersonal relationships oriented towards the common $\operatorname{good}^{17}$.

\section{Gospel shows new perspectives of life}

The way of understanding the integral development presented above indicates the twofold role performed by religion ${ }^{18}$. First of all, if we intend to speak about integral upbringing, then religious development should be placed in the same field as the person's development assuming his/her dimensions of personality. Secondly, the more important thing seems to be the fact that one should take care of a person in terms of obtaining by her/him a reasonable explanation of own appropriate or inappropriate expression of emotions or the need of choosing the right value, as it takes place in integral upbringing. What is more, this religious reality should become a crucial reference to human activity and behaviour while explicating her/his existence. One can imply that in the integral upbringing religion ought to be a point of reference, or a common dominator in explicating matters of human life.

16 Janusz Krysztofik, Anna Walulik, Między ignorancją a eksperckościa. Edukacja religijna w kształtowaniu codzienności dorosłych (Częstochowa: Edycja Świętego Pawła, 2016).

17 Tadeusz Ślipko, Janusz Mółka, „Godność człowieka w świetle etyki”, in: Godność jako wartość i problem edukacyjny, ed. Iwona Jazukiewicz, Andrzej M. de Tchorzewski (Szczecin: Wydawnictwo Naukowe Uniwersytetu Szczecińskiego, 2016), 54.

18 Anna Walulik, „Religia w kształtowaniu dorosłości. Perspektywa katolicka”, Paedagogia Christiana 2/40 (2017): 171-186. 
Thus, human life has to be perceived not in the light of its assessment, but in the assessment made in the light of God Revelation.

Considering this perspective, the religion contribution to the processes of integral development, we can notice appreciation of the meaning of trust shown to Transcendence, apart from the information of religion and faith possessed by a person. These kinds of skills help person achieve the mental, intellectual, volitive and emotional competences that enable her/him to understand in more complex way own place in the world ${ }^{19}$. In this case, one of the valid factors supporting the processes of integral upbringing, understood in such a way, means the approval of using not only natural cognition, but a religious one, as well in their trajectory.

Being conscious of the fact that contemporary world-views are usually based on the scientific rationale, one can notice that implications emerging from them often overcome boundaries appointed by logics of reason ${ }^{20}$. Therefore, one cannot explain human existence and the world only with the intellect. Here, the transgression beyond self and surrounding reality appears necessary. Nevertheless, if man does not find any support in any system of religious believes that he has to possess the support in himself, in his own conscience $^{21}$.

The veracity of this way of thinking is noticed, for instance, by Bogusław Śliwerski, who sees that in each theory of upbringing we can distinguish the transcendence dimension ${ }^{22}$. This is the reality - the mystery that man is not able to know without the explanations drawn from the religious sources. This extremely complicated process is a characteristic attribute of people from every epoch, but what it does not mean is that everyone has a similar attitude to it. What is more, one can suppose that it will be the phenomenon which the further generations are going to struggle with, for the sociologists resign of announcing the end of religion and the beginning of completely secular epoch $^{23}$. This thought leads to the implication that the object of integral up-

19 Janusz Krysztofik, Anna Walulik, „Edukacja religijna i jej miejsce w ponowoczesności”, Studia Katechetyczne 12 (2016): 35-50.

${ }^{20}$ Paweł Kamela, „O pojęciu światopoglądu”, Studia Iuridica XXXIV (1997): 25-26; por. Marian Rusecki, Paweł Sokołowski, „Światopogląd”, in: Encyklopedia katolicka, t. XIX, ed. Edward Gigilewicz (Lublin: TN KUL, 2013), 335.

${ }^{21}$ Bogusław Śliwerski, Współczesne teorie i nurty wychowania (Kraków: Impuls, 2015), 208.

22 Śliwerski, „Pedagogika”, 98.

23 Janusz Mariański, „Przedmowa”, in: Dariusz Tułowiecki, Bez Boga, Kościoła i zasad? (Kraków: Petrus, 2012), 7. 
bringing should be identified not only with the man's biological sphere, but with the spiritual one inspired by social and cultural contexts ${ }^{24}$.

Although spirituality can have the non-religious character as well, the fulfilment of man's spiritual needs aligned with the integral upbringing is primarily possible thanks to religious cognition ${ }^{25}$. It enables man to discover reality beyond the capacity of his intellectual cognition defending him from ontologism, scientism, eclecticism, pragmatism or rationalism ${ }^{26}$. As far as the knowledge gained by intellect is considered as motivated and certain, the cognition which means the spiritual acquisition of everything that makes the existence certain on the basis of the cognition coming from own insight and experience, the knowledge gained with the religious cognition teaches us how to possess a new look and insight at own experience and take over the particular principles and views that come from another person's authority and witness.

In Christian understanding, this person is appointed as the personal God. He discloses the truth to man, who is not able to cover it with his intellect. This truth broadens the horizons of human cognition and permits us to access the mystery in which the man's existence is plunged. However, the condition to accept the religious cognition means not only the acceptance of God's existence but, primarily, having personal contact with Him and showing Him obedience. All these things make us self-aware of the fact that religious cognition is placed in the same rank as natural one. That is why, it is important to make self-conscious that even though both forms of cognition complete each other evenly, each of them has a different range of cognition.

\section{Gospel discloses a new quality of life}

In the context of the Bible pericope analysed, one more detail is worth paying attention to. The young man asks Jesus: "Teacher, what good thing must I do to get eternal life?" (v. 16). It is a question about the goal and quality of his life and what is more - about its sense. For better understanding of

${ }^{24}$ Marian Nowak, „Integralność w formacji kapłańskiej. Implikacje i wnioski dla projektów formacyjnych sformułowanych w nowym Ratio fundamentalis institutionis sacerdotalis", Formatio Permanens 17 (2017): 34-36.

${ }_{25}$ Marek, Pedagogika, 90-94.

${ }^{26}$ Wojciech Cichosz, Wychowanie chrześcijańskie wobec postmodernistycznej prowokacji (Gdańsk: Zakłady Graficzne im. KEN, 2001), 195. 
the young man's thinking here, we can add that life in the Bible is not treated as having a 'neutral' quality: for example, as main power of outer-space development. It is regarded as the highest good, state and possession to have been given to man.

The Bible depicts life as reality, with its greatness originated from God. It occurs in front of God and is directed towards God. First of all, God has life inside Himself; God makes everything alive - exist including man. Thus, $\mathrm{He}$ is the wholeness of life, and its Lord ${ }^{27}$. The size of its possession we can find in scale of fulfilling God's will by man, in someone's contribution to the development of the world that realises God's law.

Jesus often identifies with treasure the possibility of life understood this way, showing the incomprehensible way of reaching it for people: "If you want to be perfect, go, sell your possessions and give to the poor, and you will have treasure in heaven. Then come, follow me!" (w. 21). With this invitation He points out the need of assessment. The man has the feeling that thanks to the item he possesses, what he gained, he can provide himself "eternal life". However, Jesus refers to the need of such thinking to be changed. Not that the items gained are somehow able to provide the man the life success, eternal life, but the contrary; their resignation and decision to follow Jesus, who can be defined as the man's treasure, is the value guaranteeing the final success of life which is reaching eternal life.

Jesus indicates the rules of man's functioning, in which love is to dominate and where love is understood as the care of another man's good according to desiring it for self. This indicates a crucial function for understanding the essence of processes of integral upbringing. The development and accomplishment of a higher and higher level of perfection demands the permanent resignation of something what appears good, but what can inhibit the man's growth. The pericope analysed outlines the perspective of giving a new quality to the human life.

Primary, it is the willingness to go beyond one's own limitations and it is this willingness we can see in the young man's attitude. He is conscious of life achievements but he sees them as insufficient. This is why, he asks Jesus: "What good thing must I do?" This question seems to be up-to-date in the case of reflection upon conditions which should appear in the order of the harmonious growth of a person and therefore his/her integral development.

27 Odilo Kaiser, „Życie”, in: Praktyczny stownik biblijny, ed. Anton Grabner-Haider (Warszawa: IW PAX, Wyd. Księży Pallotynów, 1994), 1509-1511. 
Making this reflection more detailed, we can state that while organising the processes of integral development, it is necessary to define the range of acts of doing supporting the initiated processes. One of these acts of doing is treating pupils in terms of personal subjective perception that they see themselves in. In the pericope analysed, this element seems to be particularly noticeable in Jesus' factual, concrete, answers. The quality of such approach is to facilitate the brought-up person's self-perception in the personal categories - I am "someone", not in the object categories defined by the noun "something', where I am "something" 28 .

Thanks to the personal subjective perception of pupil, the relationships made by him/her enable to make choices inspired by the gained knowledge, possessed freedom and growing responsibility. As mentioned above, personal subjectivity - which should be the basis for the integral upbringing - is assumed to be understood broadly as 'Being' with the person. This principle refers to the pupils in a particular way. Hence, we can talk about an educative accompaniment. It is not a matter of constant supervision which, in fact, deprives the person of the law to secure his freedom and, in consequence, personal-subjectivity but discretely accompanying her/his development ${ }^{29}$. It is to serve as a means of gaining the knowledge, making research, describing, explaining and interpreting this part of social reality which responds to bringing up $\operatorname{man}^{30}$. The impulses for this reflection are supplied by the pedagogy of accompaniment in which fundamental assumptions arise from the pedagogy inspired by the spiritual exercises worked out by Ignatius of Loyola $^{31}$. The method of work used by participants in retreats who do exercises with their supervisor, depicts that it can be applied not only in the domain of religious life.

This form of pedagogical accompaniment that we meet in the evangelical pericope, describes the meeting between Jesus and the young man. From

${ }^{28}$ Por. Zbigniew Marek, Religia pomoc czy zagrożenie dla edukacji (Kraków: WAM, 2014), 16nn.

29 Por. Marek, Pedagogika.

${ }^{30}$ Andrzej M. de Tchorzewski, Wstęp do teorii wychowania (Kraków: WSFP „Ignatianum", WAM, 2016), 43.

31 Janusz Mółka, „Personalistyczny paradygmat pedagogiki ignacjańskiej”, in: Paradygmaty akademickiego kształcenia pedagogów, eds. Anna Sajdak, Danuta Skulicz (Kraków: Wydawnictwo Uniwersytetu Jagiellońskiego, 2010), 219-227; Janusz Mółka, „Samorealizacja w założeniach pedagogiki ignacjańskiej”, in: Pedagogika ignacjańska. Historia, teoria, praktyka, ed. Anna Królikowska (Kraków: WSFP „Ignatianum”, WAM, 2010), 239-250. 
their talk, we may learn that the young man possessed a property, acknowledged within a system of value - the commandments - and looked for the conformity of rightness of his own actions in line with Jesus. First of all, it is surprising to learn in this talk that Jesus does not stop upon what is the young man's contribution. It is in fact the opposite; He draws him towards new ideals of life connected not with possessing but being a different person from now: "If you want to be perfect" (v. 21). This announcement by Jesus pays attention to the significance of drawing new ideas, such as "be perfect" in the processes of upbringing. In the speculation, emerging from Jesus invitation, "Then come, follow Me!" (v. 21), we shall add that this perfection is to overcome the human being way of understanding it, as following Jesus leads to reaching the 'treasure' that He is himself. This way Jesus draws the young man's attention to every pupil to non-material, spiritual reality ${ }^{32}$.

In the light of explanations shown above, one should not be puzzled by an appreciation of the educative meaning of Gospel in the processes of integral upbringing. Besides, one should notice that just Jesus Christ draws upon the ideal of life named by Saint Paul as "a new man". The term "a new man" has a theological tone, defining the person who takes the formal speech of Gospel and is baptised to bring a new quality to life. This new quality comes from personal unity and life with Jesus Christ. Its significant feature should be unconditioned servitude to man. This shape seems to be particularly current for integral upbringing: the servitude to man inspired by the motives drawn from relationship with Transcendence - God.

Owing to the fact that the integral upbringing is set in the streamline of transcendental pedagogy, we can say that it supports pursuits to more complete perception and formation of man, and so significantly fosters both his corporal and spiritual development. Among the possibilities supporting man in achieving maturity are the activities coming from a literal reading Gospel. As the analysis shown in the upbringing practice, they can take place through the use of the achievements of the pedagogy of accompaniment. Thus, thanks to the upbringing activities, it is more possible to open the person towards the non-material world and Transcendence itself; in other words, towards a personal God.

All these elements ensure that the Gospel gives man new perspectives of seeing reality, while the integral upbringing discloses a new quality of life

32 Por. Zbigniew Marek, „Duchowość, religia i wychowanie”, Pedagogika Społeczna 1 (2015): 9-22. 
to both pupil and form-teacher that emerges from the subjective perception of man. It not only enables man to get and develop the interpersonal relationships with the people, but also the relationship with God. The last things broaden the scope of man's reflection upon self and disclose new dimensions of his nature and dignity to him. All these aspects make the man conscious of the fact that Christian religion and Gospel are the foundation that supplies an upbringing with new tools which support its processes. The pedagogical value of Gospel means primary opening the man up to the transcendental reality, while also showing him the means of its achievement and the use of values comprised by it.

\section{References}

Bagrowicz, Jerzy. „Godność osoby fundamentem wychowania”. In: Wychowanie personalistyczne, ed. Franciszek Adamski, 179-212. Kraków: WAM, 2005.

Beck, Eleonore. „Dekalog”. In: Praktyczny stownik biblijny, ed. Anton Grabner-Haider, 228-229. Warszawa: IW PAX, Wyd. Księży Pallotynów, 1994.

Charytański, Jan. Rzeczywistość miłości w Katechizmie Kościoła katolickiego. Kraków: WAM, 1998.

Cichosz, Wojciech. Wychowanie chrześcijańskie wobec postmodernistycznej prowokacji. Gdańsk: Zakłady Graficzne im. KEN, 2001.

Jan Paweł II. Fides et ratio. Poznań: Pallottinum, 1998.

Kaiser, Odilo. „Życie”. In: Praktyczny stownik biblijny, ed. Anton Grabner-Haider, 1509-1511. Warszawa: IW PAX, Wyd. Księży Pallotynów, 1994.

Kamela, Paweł. „O pojęciu światopoglądu”. Studia Iuridica XXXIV (1997): 25-32.

Katechizm Kościoła Katolickiego. Poznań: Pallottinum, 1994.

Krysztofik, Janusz, Anna Walulik. „Edukacja religijna i jej miejsce w ponowoczesności”. Studia Katechetyczne 12 (2016): 35-50.

Krysztofik, Janusz, Anna Walulik. Między ignorancja a eksperckością. Edukacja religijna w kształtowaniu codzienności dorostych. Częstochowa: Edycja Świętego Pawła, 2016.

Leske, Adrian. „Ewangelia według św. Mateusza”. In: Międzynarodowy komentarz do Pisma Świętego. Komentarz katolicki i ekumeniczny na XXI wiek, ed. Waldemar Chrostowski, 1133-1205. Warszawa: Verbinum, 2000.

Marek, Zbigniew, Anna Walulik. „Pedagogika katolicka w perspektywie pedagogiki transcendentnej”. Horyzonty Wychowania 38 (2017): 125-141.

Marek, Zbigniew, Anna Walulik. Pedagogika świadectwa. Perspektywa antropologiczno-kerygmatyczna. Kraków: AIK, (w druku). 
Marek, Zbigniew. „Duchowość, religia i wychowanie”. Pedagogika Społeczna 1 (2015): 9-22.

Marek, Zbigniew. Pedagogika towarzyszenia. Perspektywa tradycji ignacjańskiej. Kraków: AIK, 2017.

Marek, Zbigniew. Podstawy wychowania moralnego. Kraków: WSF-P „Ignatianum", WAM, 2005.

Marek, Zbigniew. Religia pomoc czy zagrożenie dla edukacji. Kraków: WAM, 2014.

Mari, Giuseppe. „Chrześcijaństwo a humanizm. Szanse i wyzwania w zsekularyzowanej kulturze". Paedagogia Christiana 1/39 (2017): 11-28. http://dx.doi. org/10.12775/PCh.2017.001.

Mariański, Janusz. „Przedmowa”. In: Dariusz Tułowiecki, Bez Boga, Kościoła i zasad?, 5-11. Kraków: Petrus, 2012.

Michalski, Jarosław. „Kształcenie ogólne czy specjalistyczne? A może jedno i drugie...". Paedagogia Christiana 1/29 (2012): 179-208. http://dx.doi.org/10.12775/ PCh.2012.010.

Mółka, Janusz, Tadeusz Ślipko. „Godność człowieka w świetle etyki”. In: Godność jako wartość i problem edukacyjny, eds. Iwona Jazukiewicz, Andrzej M. de Tchorzewski, 47-60. Szczecin: Wydawnictwo Naukowe Uniwersytetu Szczecińskiego, 2016.

Mółka, Janusz. „Personalistyczny paradygmat pedagogiki ignacjańskiej”. In: Paradygmaty akademickiego ksztatcenia pedagogów, eds. Anna Sajdak, Danuta Skulicz, 219-227. Kraków: Wydawnictwo Uniwersytetu Jagiellońskiego, 2010.

Mółka, Janusz. „Samorealizacja w założeniach pedagogiki ignacjańskiej”. In: Pedagogika ignacjańska. Historia, teoria, praktyka, ed. Anna Królikowska, 239-250. Kraków: WSFP „Ignatianum”, WAM, 2010.

Nowak, Marian. „Integralność w formacji kapłańskiej. Implikacje i wnioski dla projektów formacyjnych sformułowanych w nowym Ratio fundamentalis institutionis sacerdotalis". Formatio Permanens 17 (2017): 34-36.

Olbrycht, Katarzyna. „Wychowanie do wartości - w centrum aksjologicznych dylematów współczesnej edukacji”. Paedagogia Christiana 1/29 (2012): 89-104. http://dx.doi.org/10.12775/PCh.2012.005.

Rusecki, Marian, Paweł Sokołowski. „Światopogląd”. In: Encyklopedia katolicka, vol. XIX, ed. Edward Gigilewicz, 335-338. Lublin: TN KUL, 2013.

Śliwerski, Bogusław. „Pedagogika bez transcendencji”. In: Pedagogika ignacjańska wobec wyzwań wspótczesnego humanizmu/Ignatian Pedagogy for the Challenges of Humanizm Today. Kraków: WSFP „Ignatianum”, WAM, 2008.

Śliwerski, Bogusław. Wspótczesne teorie i nurty wychowania. Kraków: Impuls, 2015. Tchorzewski, de Andrzej M. Wstęp do teorii wychowania. Kraków: WSFP „Ignatianum", WAM, 2016. 
Waldenfels, Hans. O Bogu, Jezusie Chrystusie i Kościele dzisiaj. Teologia fundamentalna w kontekście czasów obecnych. Katowice: Księgarnia św. Jacka, 1993.

Walulik, Anna. „Religia w kształtowaniu dorosłości. Perspektywa katolicka”. Paedagogia Christiana 2/40 (2017): 171-186. DOI: http://dx.doi.org/10.12775/ PCh.2017.031. 